\title{
mau \\ Optimization of Friction Stir Processing Parameters of Recycled AA 6063 for Enhanced Surface Microhardness and Tribological Properties
}

\author{
Guo Sheng Teo, Kia Wai Liew * and Chee Kuang Kok (])
}

check for

updates

Citation: Teo, G.S.; Liew, K.W.; Kok C.K. Optimization of Friction Stir Processing Parameters of Recycled AA 6063 for Enhanced Surface Microhardness and Tribological Properties. Metals 2022, 12, 310. https://doi.org/10.3390/ met12020310

Academic Editors: Young-Sik Pyun, Do-Sik Shim and Marcello Cabibbo

Received: 27 December 2021

Accepted: 4 February 2022

Published: 10 February 2022

Publisher's Note: MDPI stays neutral with regard to jurisdictional claims in published maps and institutional affiliations.

Copyright: (c) 2022 by the authors. Licensee MDPI, Basel, Switzerland. This article is an open access article distributed under the terms and conditions of the Creative Commons Attribution (CC BY) license (https:/ / creativecommons.org/licenses/by/ $4.0 /)$.
SIG: Machine Design and Tribology, Centre for Advanced Mechanical and Green Technology, Faculty of Engineering and Technology, Multimedia University, Jalan Ayer Keroh Lama, Melaka 75450, Malaysia; jesmen827@gmail.com (G.S.T.); ckkok@mmu.edu.my (C.K.K.)

* Correspondence: kwliew@mmu.edu.my or mscalec@gmail.com; Tel.: +60-606-252-3507

\begin{abstract}
This work aims to optimize the friction stir processing parameters of recycled aluminum alloy 6063 for enhanced mechanical and tribological properties. The selected friction stir processing parameters that were used to produce friction stir processed recycled aluminum alloy 6063 are tool rotational speeds and feed rates ranging from $1200 \mathrm{rpm}$ to $2000 \mathrm{rpm}$ and $25 \mathrm{~mm} / \mathrm{min}$ to $45 \mathrm{~mm} / \mathrm{min}$, respectively. The surface microhardness of the friction stir processed samples were measured and the friction and wear tests were conducted using a pin-on-disc tribo-tester under starved lubrication conditions. The results show that the optimum friction stir process parameters for recycled aluminum alloy 6063 are $1200 \mathrm{rpm}$ and $30 \mathrm{~mm} / \mathrm{min}$. Friction stir processed recycled aluminum alloy 6063 produced by these parameters led to enhancement of microhardness and the wear resistance by $25 \%$ and $37 \%$, and reduction of friction coefficient and grain size by about $33 \%$ and $96 \%$, respectively.
\end{abstract}

Keywords: friction stir processing; recycled AA 6063; FSP parameters optimization; surface microhardness; tribological properties

\section{Introduction}

Aluminum alloy is an important engineering material due to its good mechanical properties and recyclability [1]. It has been recycled since it was first commercially produced and its quality is not impaired after recycling [2]. The 6XXX aluminum alloy (an aluminum alloy with major alloying of magnesium and silicon) is heat treatable, has good corrosion resistance, good extrudability and hence, it has been widely used in furniture, automotive, structural components, and many more [3-6]. In some applications, material property enhancement is required and this can be done by refining the grain size of the material [7]. In recent times, there is an energy-efficient and environmentally-friendly technique that can enhance the material properties by refining the grain size of the material, and this method is known as friction stir processing (FSP) [8-10]. FSP is a surface engineering technique that was developed from friction stir welding (FSW) and invented by The Welding Institute (TWI) in the year 1991 [11,12]. FSP modifies material properties by using a special-designed friction stir tool to generate friction heat under optimum processing parameters $[13,14]$. An aluminum alloy that is processed by FSP can be used for ship cradle and journal bearing. FSP parameters are very important as they may affect the outcomes of this process. According to previous studies, the most significant parameters that had been studied are the rotational speed and the feed rate as they control the heat generation that results in plasticized and material flow during the process [11].

Aluminum alloy 6063 (AA 6063) is good in weldability and has been widely used in both FSW and FSP. It was noted that producing FSPed materials with the desired performance requires suitable processing parameters for sufficient heat generation. With regard to FSPed AA 6063, the processing parameters such as rotational speed and feed 
rate have been emphasized in previous FSP works. The rotational speed that was used for FSPed AA 6063 varied among others and it ranges from $315 \mathrm{rpm}$ to $3500 \mathrm{rpm}$ while the feed rate ranges from $40 \mathrm{~mm} / \mathrm{min}$ to $1000 \mathrm{~mm} / \mathrm{min}[6,7,15-18]$. Karthikeyan L. et al. [6] used regression analysis to predict the FSP results and the predicted results showed a good correlation with the experimental results that a rotational speed of $1200 \mathrm{rpm}$ to $1400 \mathrm{rpm}$ with a feed rate of $40.2 \mathrm{~mm} / \mathrm{min}$ produced FSPed samples with enhancement. Excessive heat input caused by higher rotational speed will lead to a reduction in material strength. Besides, reduction in strength and hardness of multi-pass of FSPed AA 6063 has also been reported by Al-Fadhalah K.J. et al. [7] due to precipitate dissolution and the limited re-precipitation caused by the thermal cycle of FSP. Besides, Zhao H.L. et al. and Mahmoud T.S. et al. $[17,18]$ also reported that increasing rotational speed increased process temperature, leading to grain coarsening in FSPed AA 6063. In the FSP of non-aluminum alloy materials, the reduction in strength and hardness were also reported and these may be due to excessive heat input leading to grain growth [19-21].

On the other hand, the rotational speed and feed rate used in the fabrication of AA 6063 surface metal matrix composites (SMMCs) range from $1120 \mathrm{rpm}$ to $1600 \mathrm{rpm}$ and $30 \mathrm{~mm} / \mathrm{min}$ to $63 \mathrm{~mm} / \mathrm{min}$ [22-25], respectively. Surface composites produced by FSP also require suitable heat input to ensure a good distribution of reinforced particles. Sandeep R. et al. [23] who worked on FSPed AA 6063/SiC reported that insufficient heat generated at $900 \mathrm{rpm}$ of rotational speed resulted in poor material flow and the reinforced particles were not distributed uniformly. He also reported that a rotational speed of $1120 \mathrm{rpm}$ produced better particles distribution than $900 \mathrm{rpm}$ and $1400 \mathrm{rpm}$. In addition, Srivastava M. et al. [24] who worked on FSPed AA 6063 also mentioned the significant impact of rotational speed and feed rate on the heat generation and the distribution of reinforced particles in his work. He reported that higher rotational speed and lower feed rate ensured a more uniform distribution of reinforced particles. He concluded that feed rate of $40 \mathrm{~mm} / \mathrm{min}$ and rotational speed of $1400 \mathrm{rpm}$ produced sufficient heat for the reinforcement while feed rate of $30 \mathrm{~mm} / \mathrm{min}$ generated excessive heat that would result in annealing of the base matrix which lowered the microhardness. Besides, a feed rate of $50 \mathrm{~mm} / \mathrm{min}$ had also produced insufficient heat during the process.

There are different combinations of rotational speeds and feed rates that have been used in FSPed AA 6063 studies. Besides, most works emphasized the mechanical properties instead of the tribological properties of FSPed samples. Hence, this work is to optimize FSP parameters for simultaneously maximized surface hardness and minimized friction and wear performance of recycled AA 6063.

\section{Materials and Methods}

\subsection{Substrate Material}

Recycled AA 6063 was selected as a substrate material in this study and its chemical composition is shown in Table 1 . Figure 1 shows the aluminum billets with a diameter of $127 \mathrm{~mm}$ and length of $350 \mathrm{~mm}$ that were cut into rectangular bars with dimensions of $110 \times 36 \times 25 \mathrm{~mm}^{3}(\mathrm{~L} \times \mathrm{W} \times \mathrm{H})$ using a manual milling machine. A silicon carbide paper of 1000 grit size was used to remove the oxide layer on the surface of recycled AA 6063 rectangular bars prior to friction stir processing.

Table 1. Chemical composition of recycled AA 6063 (wt \%).

\begin{tabular}{ccccccccccc}
\hline Element & $\mathbf{Z n}$ & $\mathbf{M g}$ & $\mathbf{C u}$ & $\mathbf{S i}$ & $\mathbf{F e}$ & $\mathbf{M n}$ & $\mathbf{C r}$ & $\mathbf{N i}$ & $\mathbf{T i}$ & Al \\
\hline wt $\%$ & 0.0331 & 0.581 & 0.0338 & 0.43 & 0.309 & 0.0252 & 0.0335 & 0.0333 & 0.0269 & Balance \\
\hline
\end{tabular}




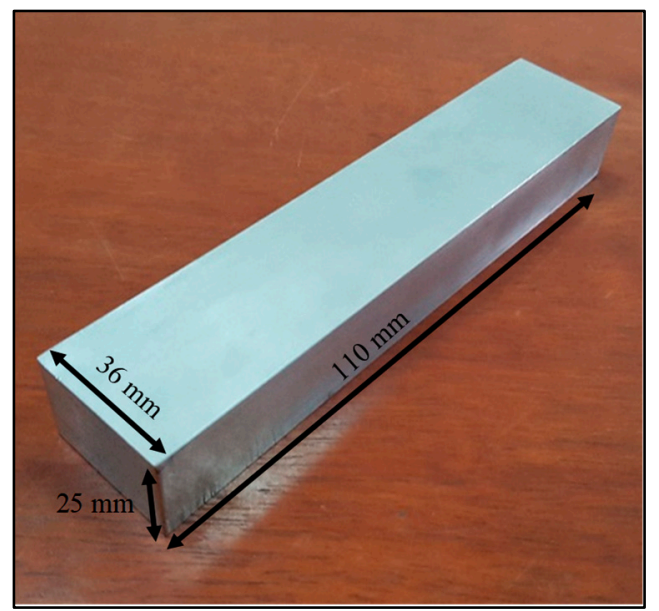

Figure 1. Recycled AA 6063.

\subsection{Friction Stir Processing (FSP)}

FSP was conducted using CNC Milling Machine, Mazak with different rotational speeds and feed rates ranging from $1200 \mathrm{rpm}$ to $2000 \mathrm{rpm}$ and $25 \mathrm{~mm} / \mathrm{min}$ to $45 \mathrm{~mm} / \mathrm{min}$, respectively. The FSP ploughing depth is $0.5 \mathrm{~mm}$. Table 2 shows the list of samples produced using different sets of processing parameters. The schematic diagrams of the FSP and FSP tool are also shown in Figure 2. Based on the authors' previous work [26], a taper threaded friction stir tool is selected and made by ASP 23 high-speed steel with 60 HRC hardness, shoulder diameter of $18 \mathrm{~mm}$, a tapered pin with a major diameter of $7 \mathrm{~mm}$, and a minor diameter of $5 \mathrm{~mm}$ and a pin length of $5 \mathrm{~mm}$ was used.

Table 2. FSPed samples with different processing parameters.

\begin{tabular}{|c|c|c|c|c|c|c|c|c|c|c|c|c|c|c|c|c|c|c|c|c|c|c|c|}
\hline Samples & 1 & 2 & 3 & 4 & 5 & 6 & 7 & 8 & 9 & 10 & 11 & 12 & 13 & 14 & 15 & 16 & 17 & 18 & 19 & 20 & 21 & 22 & 23 \\
\hline $\begin{array}{l}\text { Rotational Speed } \\
\quad\left(\times 10^{3} \mathrm{RPM}\right)\end{array}$ & 1.2 & 1.2 & 1.2 & 1.4 & 1.4 & 1.4 & 1.4 & 1.4 & 1.6 & 1.6 & 1.6 & 1.6 & 1.6 & 1.8 & 1.8 & 1.8 & 1.8 & 1.8 & 2.0 & 2.0 & 2.0 & 2.0 & 2.0 \\
\hline $\begin{array}{l}\text { Traverse Speed } \\
(\mathrm{mm} / \mathrm{min})\end{array}$ & 25 & 30 & 35 & 25 & 30 & 35 & 40 & 45 & 25 & 30 & 35 & 40 & 45 & 25 & 30 & 35 & 40 & 45 & 25 & 30 & 35 & 40 & 45 \\
\hline
\end{tabular}

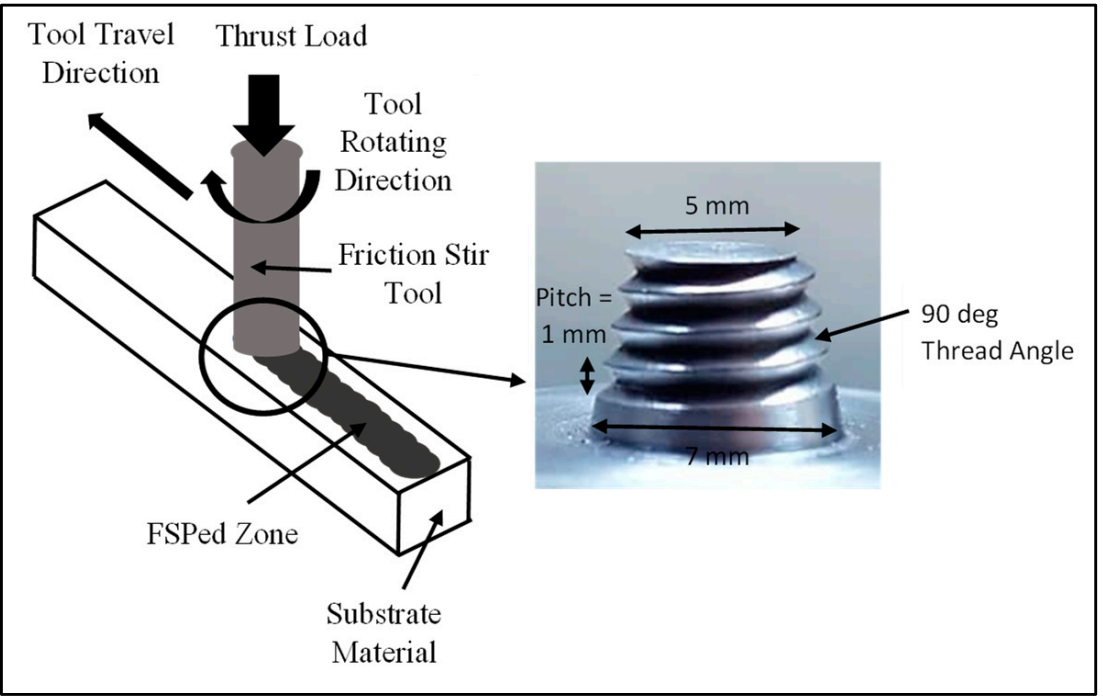

Figure 2. Schematic diagram of FSPed recycled AA 6063. 


\subsection{Surface Roughness Measurement}

The FSPed surface roughness was measured using surface profilometer, MarSurf M400 C (Mahr, Göttingen, Germany). The roughness values and the roughness profile were recorded.

\subsection{Microstructure Analysis}

The processed workpieces were cut into microstructure samples with the dimension of $36 \times 20 \times 15 \mathrm{~mm}^{3}(\mathrm{~W} \times \mathrm{L} \times \mathrm{H})$. Figure 3a shows the schematic of the sample cut from the processed workpiece and Figure $3 b$ shows the $C A D$ drawing of this sample. After grinding and polishing with 400, 600, 800, 1000, and 2000 grit sizes of water-proof silicon carbide paper and 6 microns, 3 microns, and 1 micron of diamond pastes mixed with colloidal silica, the samples were etched using Keller's Reagent. The microstructure of the FSPed recycled AA 6063 samples was inspected using the metallurgical microscope (Meiji, Saitama, Japan). The changes in the microstructure of both base metal (BM) and selected FSPed samples were observed and the grain sizes of these samples were also measured.

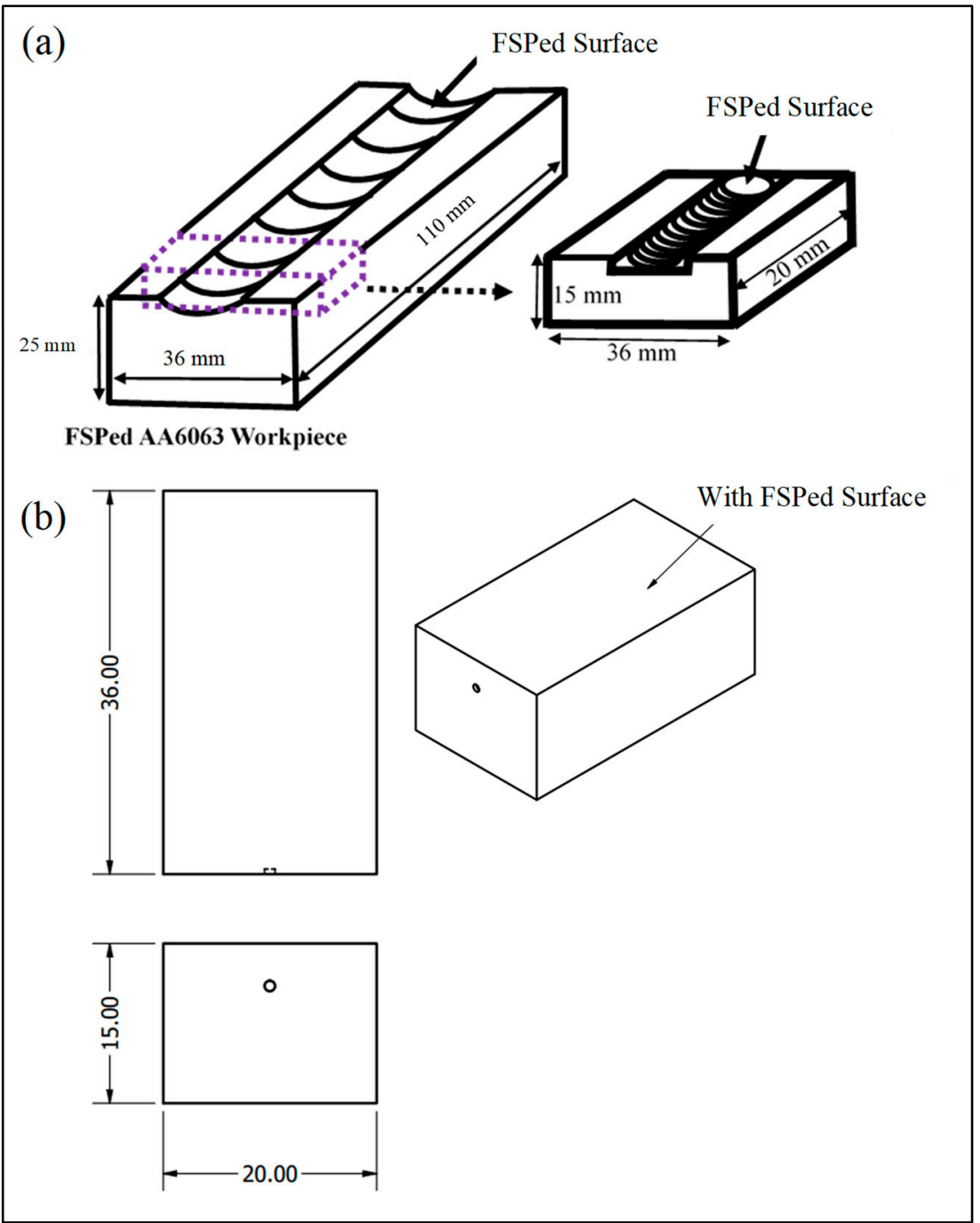

Figure 3. Microstructure and hardness test sample, (a) cut from FSPed workpiece, and (b) CAD drawing.

\subsection{Microhardness Measurement}

Microhardness measurement was conducted using Wilson 430 SVD Vickers Hardness Tester (Buehler, Lake Bluff, IL, USA). The load was set to $9.81 \mathrm{~N}$ with a dwell time of $10 \mathrm{~s}$. Prior to the measurement, the indenter was cleaned with an alcohol prep pad and 
the samples were ground and polished with 400, 600, 800, 1000, and 2000 grit sizes of water-proof silicon carbide paper and 6 microns, 3 microns, and 1 micron of diamond paste mixed with colloidal silica, until mirror finish was obtained.

\subsection{Friction and Wear Test}

The tribo-test samples with a size of $11 \times 11 \times 20 \mathrm{~mm}^{3}(\mathrm{~W} \times \mathrm{L} \times \mathrm{H})$ were cut from the FSPed workpiece as shown in Figure 4a. The CAD drawings for the tribopin and pin-on-disc tribo-tester are also presented in Figures $4 \mathrm{~b}$ and 5. Friction and wear characterization was performed by using a pin-on-disc tribo-tester and S275JR steel was used as the counter disc. The sliding test was conducted under starved lubrication conditions and the lubrication used was distilled water. The sliding test was conducted at a speed of $2.88 \mathrm{~m} / \mathrm{s}$, with a sliding distance of $1500 \mathrm{~m}$ and under a normal contact pressure of $0.24 \mathrm{MPa}$. The weight loss of the test samples was measured with an electronics balance. All the wear rate and their friction coefficient were computed and tabulated.

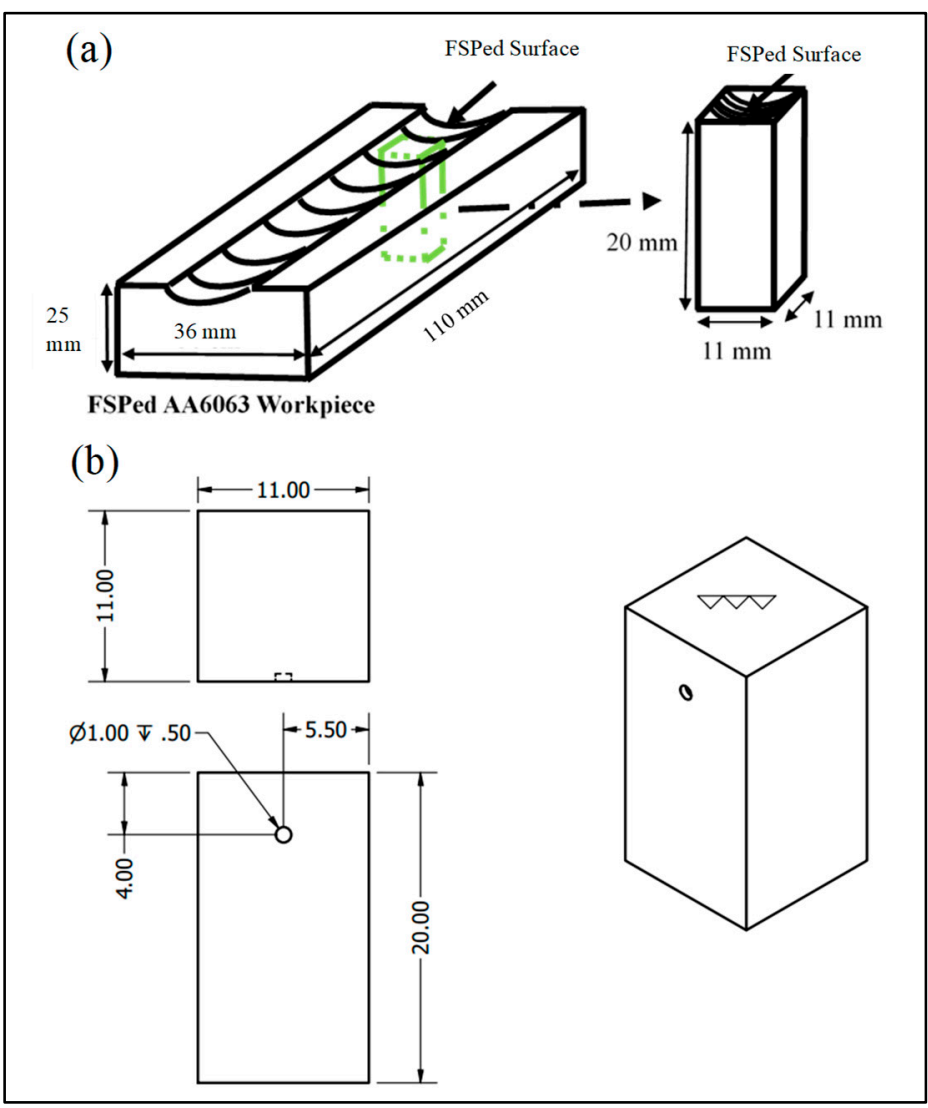

Figure 4. Tribo-test sample, (a) cut from FSPed workpiece, and (b) CAD drawing.

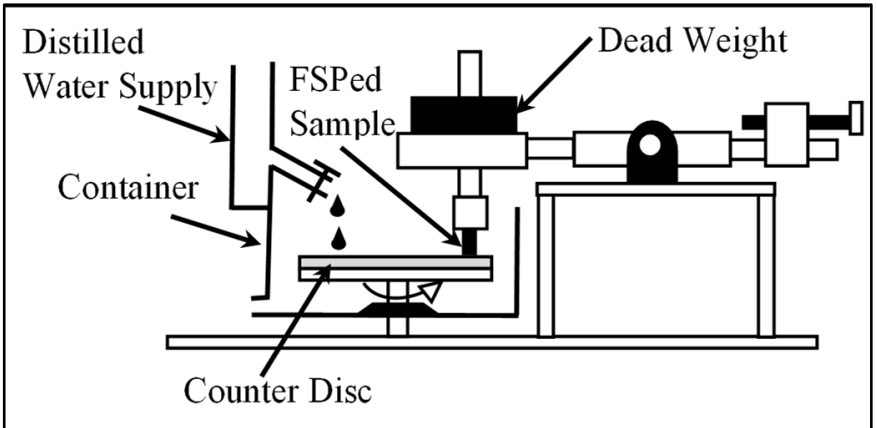

Figure 5. Pin-on-disc tribo-test schematic diagram [13]. 


\section{Results and Discussion}

\subsection{Microstructure Analysis}

Figure 6 demonstrates the microstructure of the FSPed sample produced at $1200 \mathrm{rpm}$ and $30 \mathrm{~mm} / \mathrm{min}$ (Sample 2) and it shows different zones of microstructures that were observed using the metallurgical microscope under $10 \times$ magnification. Figure 6a shows the outermost part of the sample that is not stirred by the FSP tool having a big grain size similar to the BM. Closer to the processing zone, the grain size started to diminish and this zone is known as the heat-affected zone (HAZ) as shown in Figure 6b. This zone is very similar to the base metal and the only difference is that the grain size is smaller. This resulted from the heat generated during the process. Next, close to the middle of the sample, a zone with grains that are formed by the shearing of FSP tool direction can be observed and this zone is known as the thermo-mechanical affected zone (TMAZ) as shown in Figure 6c. At the middle of the sample is the stir zone of the FSPed sample as shown in Figure $6 \mathrm{~d}$. At this zone, the fine grain can be observed, and this grain refinement was due to the plastic deformation and dynamic recrystallization during the process. A. Amirafshar et al. [5] who worked on FSPed ST14 stainless steel claimed that similar grain refinement was due to severe plastic deformation and dynamic recrystallization during FSP. Besides, P. Cavahere et al. [27] also reported the plastic deformation and dynamic recrystallization that resulted in grain refinement of FSPed AA 7075. Furthermore, refinement in microstructure was also reported in K. Surekha. Et al. [20] work and the occurrence of grain refinement are also attributed to dynamic recrystallization. N. Yasavol et al. [28] also reported that the stir zone was formed due to the plastic deformation and the thermo-mechanical affected zone was formed due to the shear direction of the FSP tool. The overall images of the intersection of stir zone, thermo-mechanical affected zone, and heat-affected zone under a $5 \times$ magnification are presented in Figure 7 . These three zones can be easily distinguished in the images by observing the difference in grain size.

The grain size of some of the FSPed samples was also measured and presented in Table 3. The outermost part of the sample (BM) that is not stirred by the FSP tool has the largest grain size and the grain size is similar to the unprocessed recycled AA 6063. Closer to the stir zone, the grain size was reduced, and the smallest grain size was observed at the stir zone. Figure 8 demonstrates grain size measurement using the metallurgical microscope software, VIS Pro, China. The maximum reduction in grain size is about $96 \%$ and the smallest average grain size was reduced to $4.6 \mu \mathrm{m}$. Besides, it also shows that the $\mathrm{BM}$ part of each sample is also similar, and their grain sizes all exceeded $100 \mu \mathrm{m}$. In addition, the microstructure also shows that the grain size becomes smaller when getting closer to the stir zone, consistent with the grain size measurement as shown in Table 3. The grain size of the heat-affected zone is about $80 \mu \mathrm{m}$ to $90 \mu \mathrm{m}$ while that in the thermo-mechanical affected zone is about $40 \mu \mathrm{m}$ to $50 \mu \mathrm{m}$. The smallest grain size was found in Sample 2, which was produced at a rotational speed of $1200 \mathrm{rpm}$ and a feed rate of $30 \mathrm{~mm} / \mathrm{min}$. As mentioned above, a reduction in grain size is due to the plastic deformation and dynamic recrystallization caused by friction heat generation [14]. Hence, the difference in grain size reduction is also due to the different amounts of plastic deformation and frictional heat generated by different processing parameters. The friction heat generation generated at $1200 \mathrm{rpm}$ and $30 \mathrm{~mm} / \mathrm{min}$ is the most sufficient for the grain refinement of the grain structure whereby the plastic deformation and dynamic recrystallization occurred and successfully refined to the smallest grain size without noticing any grain growth. However, the excessive friction heat generated by other processing parameters such as $1400 \mathrm{rpm}$ and $40 \mathrm{~mm} / \mathrm{min}, 1400 \mathrm{rpm}$ and $45 \mathrm{~mm} / \mathrm{min}$, and $1800 \mathrm{rpm}$ and $30 \mathrm{~mm} / \mathrm{min}$ has resulted in grain growth of the material during dynamic recrystallization [19-21]. 


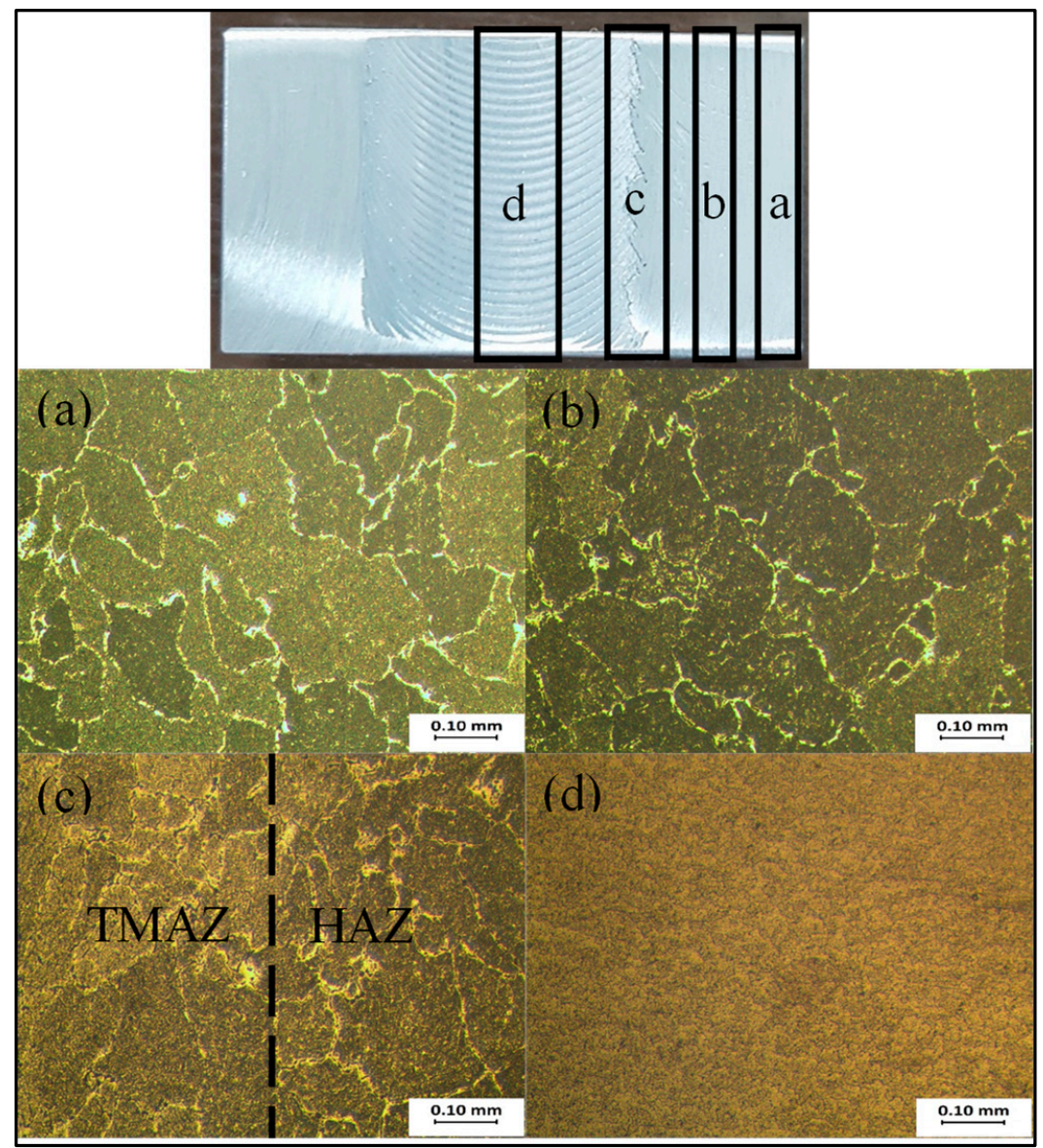

Figure 6. Microstructure of FSPed Sample $2(10 \times)$, (a) base metal, (b) heat-affected zone (HAZ), (c) intersection of the heat-affected zone (HAZ), and thermo-mechanical affected zone (TMAZ) and (d) stir zone.

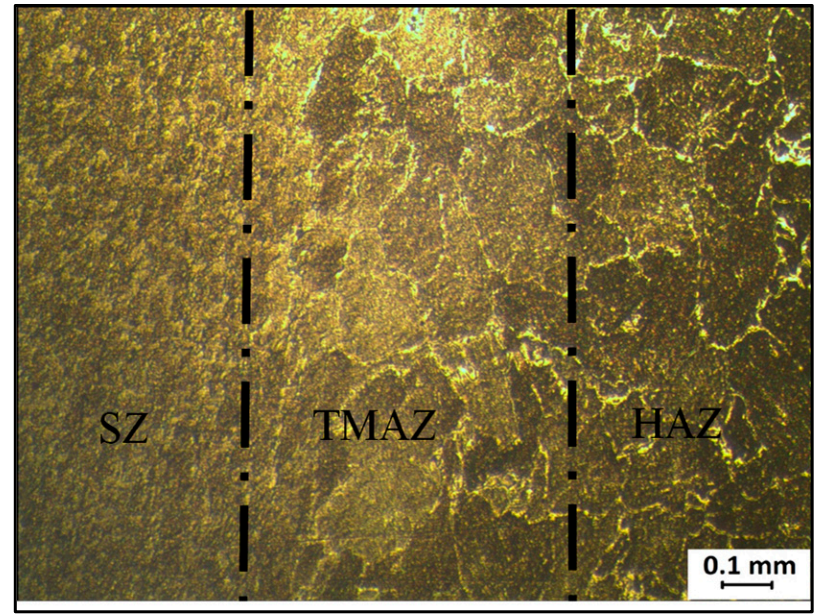

Figure 7. Microstructure of stir zone (SZ), thermo-mechanical affected zone (TMAZ), and heataffected zone (HAZ) boundary $(5 \times)$ of FSPed Sample 2 . 
Table 3. Average grain size of recycled AA 6063 base metal and FSPed samples.

\begin{tabular}{cccccc}
\hline \multirow{2}{*}{ Zones } & \multicolumn{5}{c}{ Average Radius $(\mu \mathrm{m})$} \\
\cline { 2 - 6 } & Base Metal & $\begin{array}{c}\mathbf{1 2 0 0 - 3 0} \\
(\text { Sample })\end{array}$ & $\begin{array}{c}\mathbf{1 4 0 0 - 4 0} \\
\text { (Sample 7) }\end{array}$ & $\begin{array}{c}\mathbf{1 4 0 0 - 4 5} \\
\text { (Sample 8) }\end{array}$ & $\begin{array}{c}\text { 1800-30 } \\
\text { (Sample 15) }\end{array}$ \\
\hline BM & 134.6 & 113.0 & 109.3 & 116.0 & 125.8 \\
\hline HAZ & - & 88.8 & 83.01 & 84.5 & 91.4 \\
\hline TMAZ & - & 45.1 & 58.54 & 40.6 & 43.3 \\
\hline SZ & - & 4.6 & 10.6 & 13.8 & 23.8 \\
\hline
\end{tabular}

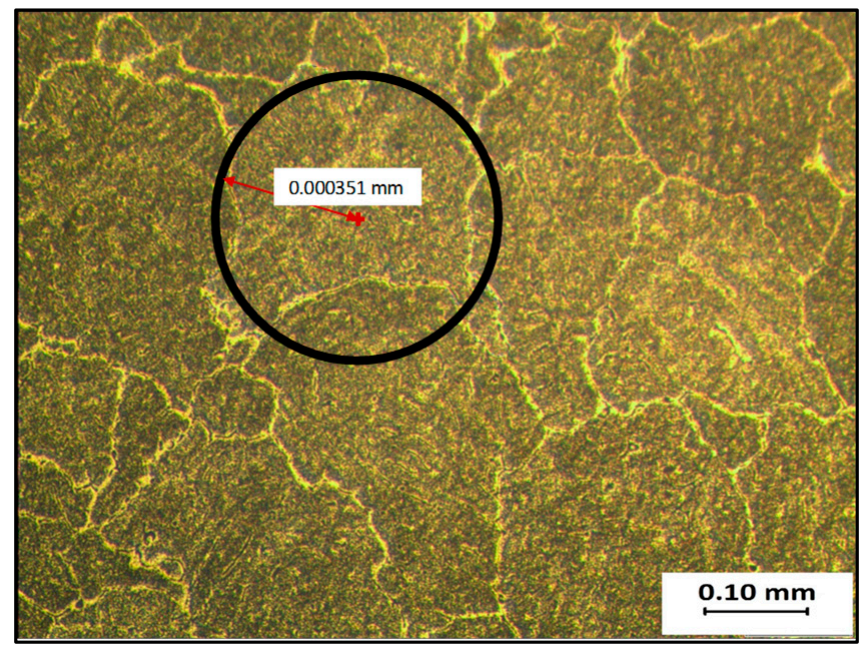

Figure 8. Grain size measurement $(10 \times)$ for the base metal part of FSPed Sample 15.

\subsection{Microhardness Measurement}

Figure 9 shows the average microhardness of all the FSPed samples and BM at the stir zone. The surface microhardness of recycled aluminum alloy BM is $38.5 \mathrm{HV} 1$ and all the FSPed samples experienced an enhancement in surface hardness. Besides, the sample produced at $1200 \mathrm{rpm}$ and $30 \mathrm{~mm} / \mathrm{min}$ (Sample 2) has the highest hardness, $48 \mathrm{HV} 1$ while the sample produced at $1800 \mathrm{rpm}$ and $30 \mathrm{~mm} / \mathrm{min}$ (Sample 15) has the lowest enhancement in the hardness of 39.34 HV1. FSP has successfully enhanced the material surface hardness up to $25 \%$. According to M.K. Mishra et al. [29] who studied friction stir processed 2507 super duplex stainless steel, enhancement in microhardness of FSPed material is due to the occurrence of grain refinement. S. Chainarong et al. and R.A. Behnagh et al. [30,31] also made the same observation of grain refinement induced enhancement in the hardness of FSPed aluminum alloy. The grain size measurement in Table 3 shows that the stir zones experience a significant reduction in grain size. Besides, Sample 2, which was produced at $1200 \mathrm{rpm}$ and $30 \mathrm{~mm} / \mathrm{min}$, has the highest hardness among all the samples and it also has the smallest grain size. Besides, Sample 7, 8, and 15 show a consistent trend that larger grain size led to lower surface hardness. Hence, this work echoes past findings that grain refinement is the cause of enhanced microhardness. 


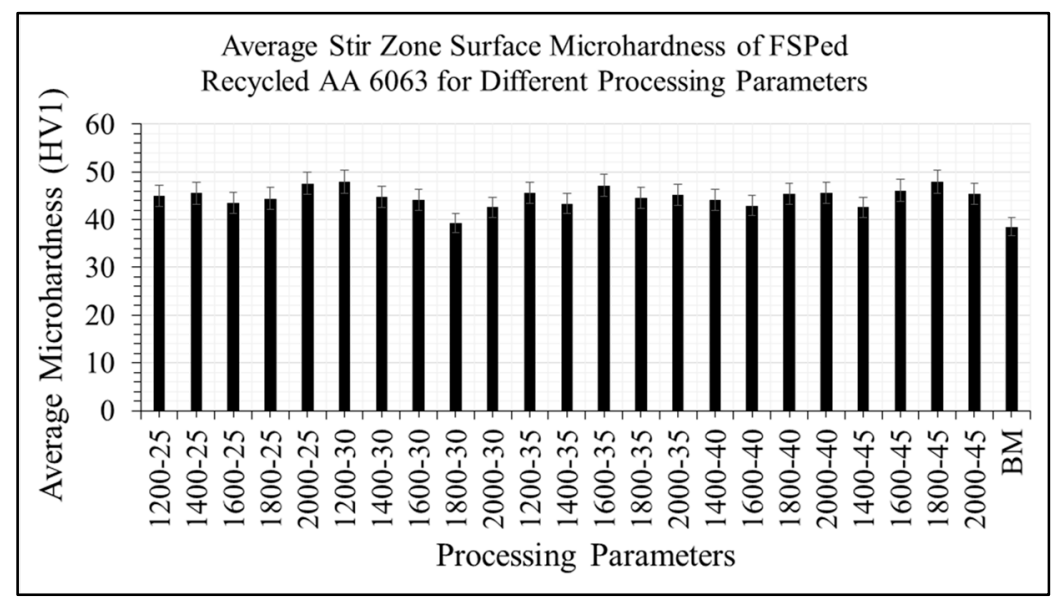

Figure 9. Average stir zone surface microhardness of FSPed samples.

\subsection{Surface Roughness Measurement}

The surface roughness of all the samples listed in Table 2 was measured and presented in Figure 10. The effects of FSP feed rates on the surface roughness have been observed. The arithmetic roughness average of the surface, $R_{a}$, and the root mean square of the surface roughness, $R_{\mathrm{q}}$, for rotational speed of $1200 \mathrm{rpm}$ increased when the feed rate increased. On the other hand, for the speed of $1400 \mathrm{rpm}, 1800 \mathrm{rpm}$, and $2000 \mathrm{rpm}$, the highest surface roughness values occurred at the feed rate of $30 \mathrm{~mm} / \mathrm{min}$ and the lowest values occurred at $40 \mathrm{~mm} / \mathrm{min}$. However, the highest roughness value for $1600 \mathrm{rpm}$ occurred at $40 \mathrm{~mm} / \mathrm{min}$ and the lowest at $45 \mathrm{~mm} / \mathrm{min}$. The effect of rotational speed on the surface roughness was examined. At the constant feed rate of $25 \mathrm{~mm} / \mathrm{min}, 30 \mathrm{~mm} / \mathrm{min}, 35 \mathrm{~mm} / \mathrm{min}$, and $45 \mathrm{~mm} / \mathrm{min}$, the highest roughness values occurred at the rotational speed of $1800 \mathrm{rpm}$. Meanwhile, at a feed rate of $40 \mathrm{~mm} / \mathrm{min}$, the highest roughness value occurred at $1600 \mathrm{rpm}$. Figure 10a,b clearly points out that the FSPed surface with the highest roughness value was found on the sample produced at $1800 \mathrm{rpm}$ and $30 \mathrm{~mm} / \mathrm{min}$ (Sample 15) with an average $R_{a}$ value of $16.87 \mu \mathrm{m}$ and $R_{q}$ values of $19.4665 \mu \mathrm{m}$. On the other hand, the surface with the smallest roughness values was produced at $1400 \mathrm{rpm}$ and $40 \mathrm{~mm} / \mathrm{min}$ (Sample 7) with an average $R_{a}$ of $0.6428 \mu \mathrm{m}$ and average $R_{q}$ value of $1.0696 \mu \mathrm{m}$.

Figure 11 shows samples of the FSPed surface and their corresponding roughness profiles. Figure $11 b$ shows the obvious onion ring that resulted in higher $R_{a}$ and $R_{q}$ values of the FSPed surface and this can be justified by the roughness profile shown in Figure 11b. On the other hand, the roughness profile of the sample produced at $1400 \mathrm{rpm}$ and $40 \mathrm{~mm} / \mathrm{min}$ as shown in Figure $11 \mathrm{a}$ has smaller $\mathrm{R}_{\mathrm{a}}$ and $\mathrm{R}_{\mathrm{q}}$ values and this can also be observed from its roughness profile as shown in Figure 11a.

To further characterize the FSPed surface roughness, the skewness, $\mathrm{R}_{\mathrm{sk}}$, and kurtosis, $R_{k u}$, values were also referred to. Based on the measurements, most of the $R_{s k}$ values for the samples produced using different processing parameters listed in Table 2 range from -0.3 to 0.8 . and their corresponding $R_{k u}$ values range from 2 to 5 . The only sample with an $R_{\text {sk }}$ value less than 0 (i.e., -0.16 ) and $R_{k u}$ value less than 3 (i.e., 2.25) is the sample produced at $1800 \mathrm{rpm}$ with $45 \mathrm{~mm} / \mathrm{min}$ (Sample 18). However, its $\mathrm{Ra}$ and $\mathrm{R}_{\mathrm{q}}$ are slightly larger at $4 \mu \mathrm{m}$ and $5 \mu \mathrm{m}$, respectively. Hence, this FSPed surface can be considered as a smooth surface. None of the other samples exhibited an $R_{s k}$ value that is less than zero and an $\mathrm{R}_{\mathrm{ku}}$ value less than 3, simultaneously. Hence, all the other FSPed surfaces are considered rough surfaces. 


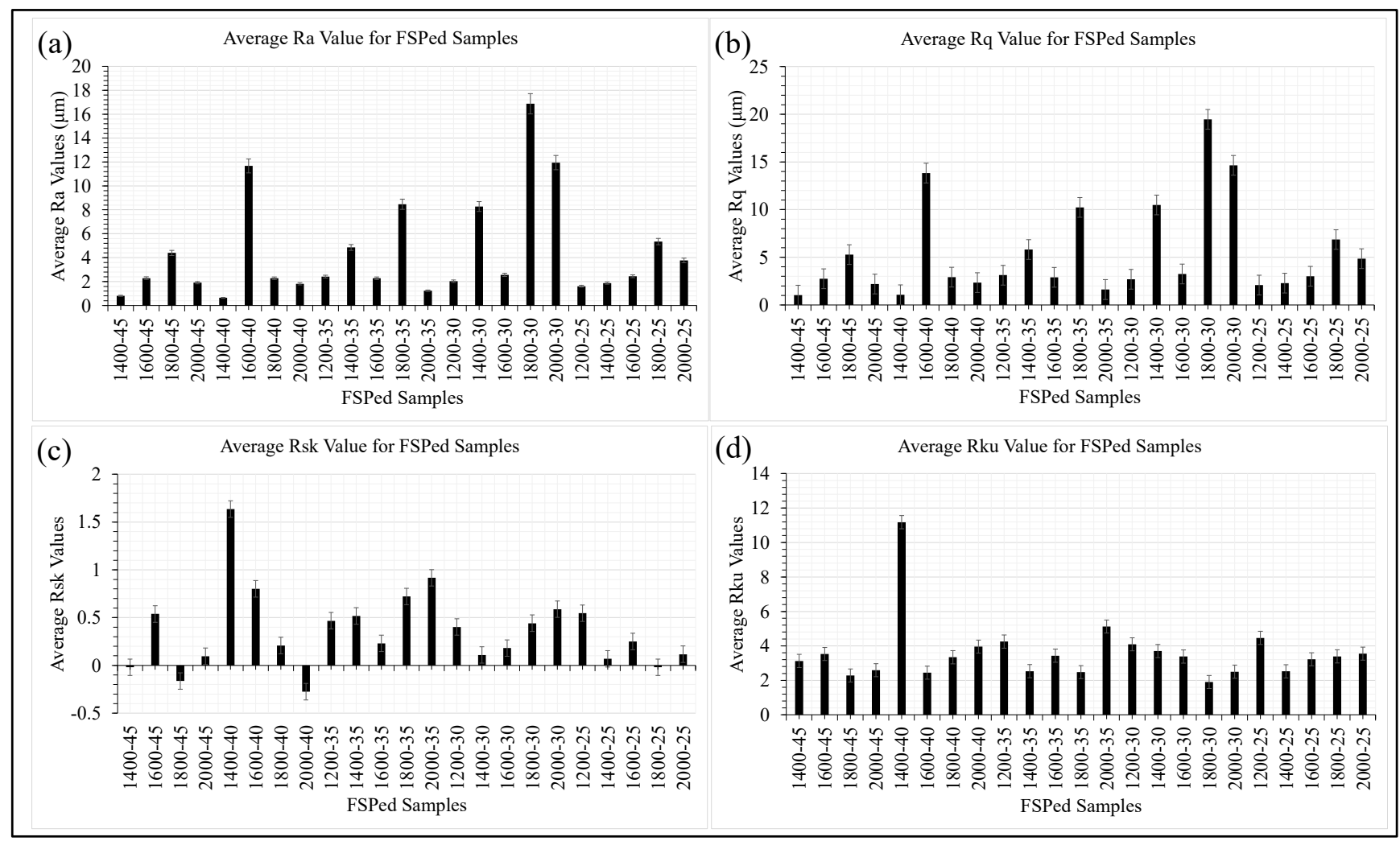

Figure 10. FSPed surface roughness, (a) average $R_{a},(b) R_{q},(c) R_{s k}$, and (d) $R_{k u}$ values.

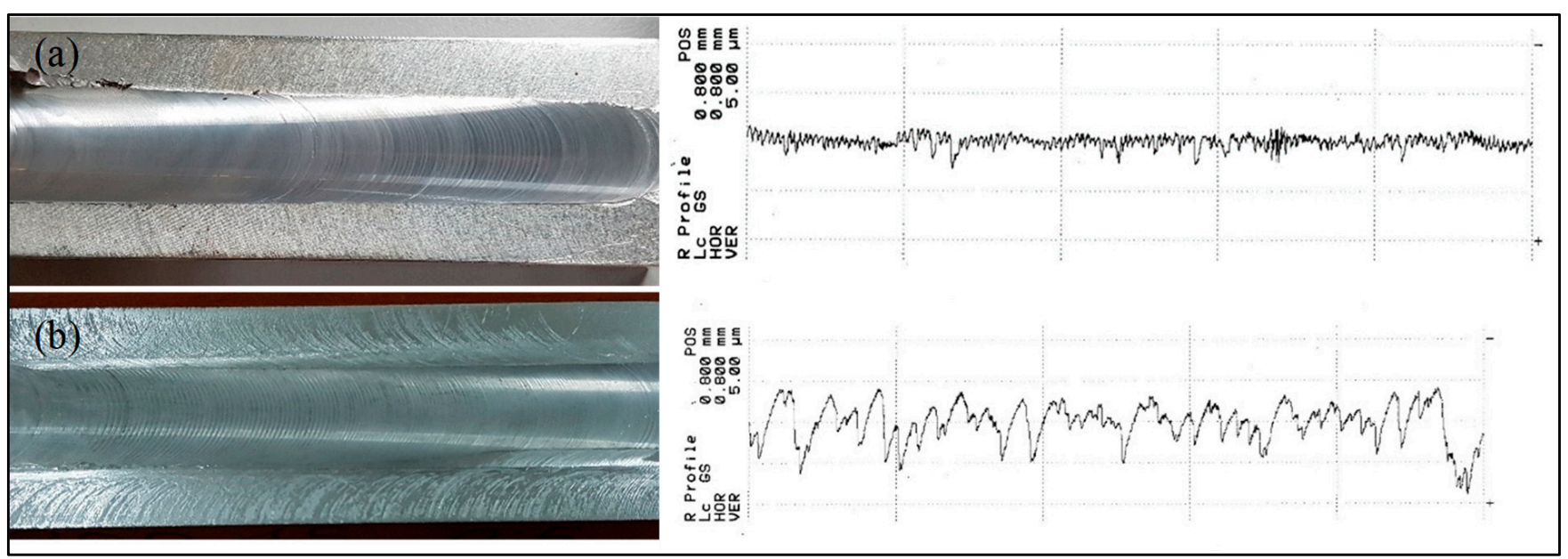

Figure 11. FSPed surface and roughness profile of (a) sample 7 and (b) sample 18.

\subsection{Tribological Performance}

The wear rate and friction coefficient of all the FSPed samples were measured. Figure 12 shows the results of the friction coefficient of FSPed samples compared with raw recycled AA 6063. The results show that all the FSPed samples have lower friction than raw recycled AA 6063. Figure 12a-c show that the smallest friction was achieved at a feed rate of $30 \mathrm{~mm} / \mathrm{min}$, and their values are 0.387 (Sample 2), 0.392 (Sample 5), and 0.427 (Sample 10) for samples produced at rotational speeds of $1200 \mathrm{rpm}, 1400 \mathrm{rpm}$, and $1600 \mathrm{rpm}$, respectively. Minimizing friction seems to require a higher feed rate at higher rotational speed, as samples produced at $1800 \mathrm{rpm}$ and $45 \mathrm{~mm} / \mathrm{min}$ (Sample 18), and $2000 \mathrm{rpm}$ and $35 \mathrm{~mm} / \mathrm{min}$ (Sample 21) were the ones yielding the lowest coefficients of friction of 0.356 and 0.415 . The friction coefficients of samples with the smallest friction at different rotational speeds were plotted as shown in Figure 13. As discussed in Section 3.3, Sample 
18 has a smooth surface and this coincides with the smallest friction coefficient among all the FSPed samples. Besides, this sample has the highest surface hardness among all the samples produced at $1800 \mathrm{rpm}$.

The second-lowest friction coefficient was achieved by FSPing at $1200 \mathrm{rpm}$ with $30 \mathrm{~mm} / \mathrm{min}$ (Sample 2). Other low friction samples that follow are those FSPed at $1400 \mathrm{rpm}$ and $30 \mathrm{~mm} / \mathrm{min}$ sample (Sample 5), $2000 \mathrm{rpm}$ and $35 \mathrm{~mm} / \mathrm{min}$ sample (Sample 21), and $1600 \mathrm{rpm}$ and $30 \mathrm{~mm} / \mathrm{min}$ (Sample 10). It is worth noting that Sample 2 also has the highest hardness among all the samples. The findings in this work align well with previous work. According to Y. Zhou et al. and B. Ivkovic et al. [32,33], a smooth surface resulted in a lower friction coefficient. D. Stamenkovic et al. [34] also reported that higher hardness led to a smaller friction coefficient. Hence, it can be concluded that the low friction coefficient of the workpiece surface is strongly correlated to both low surface roughness and high surface hardness.

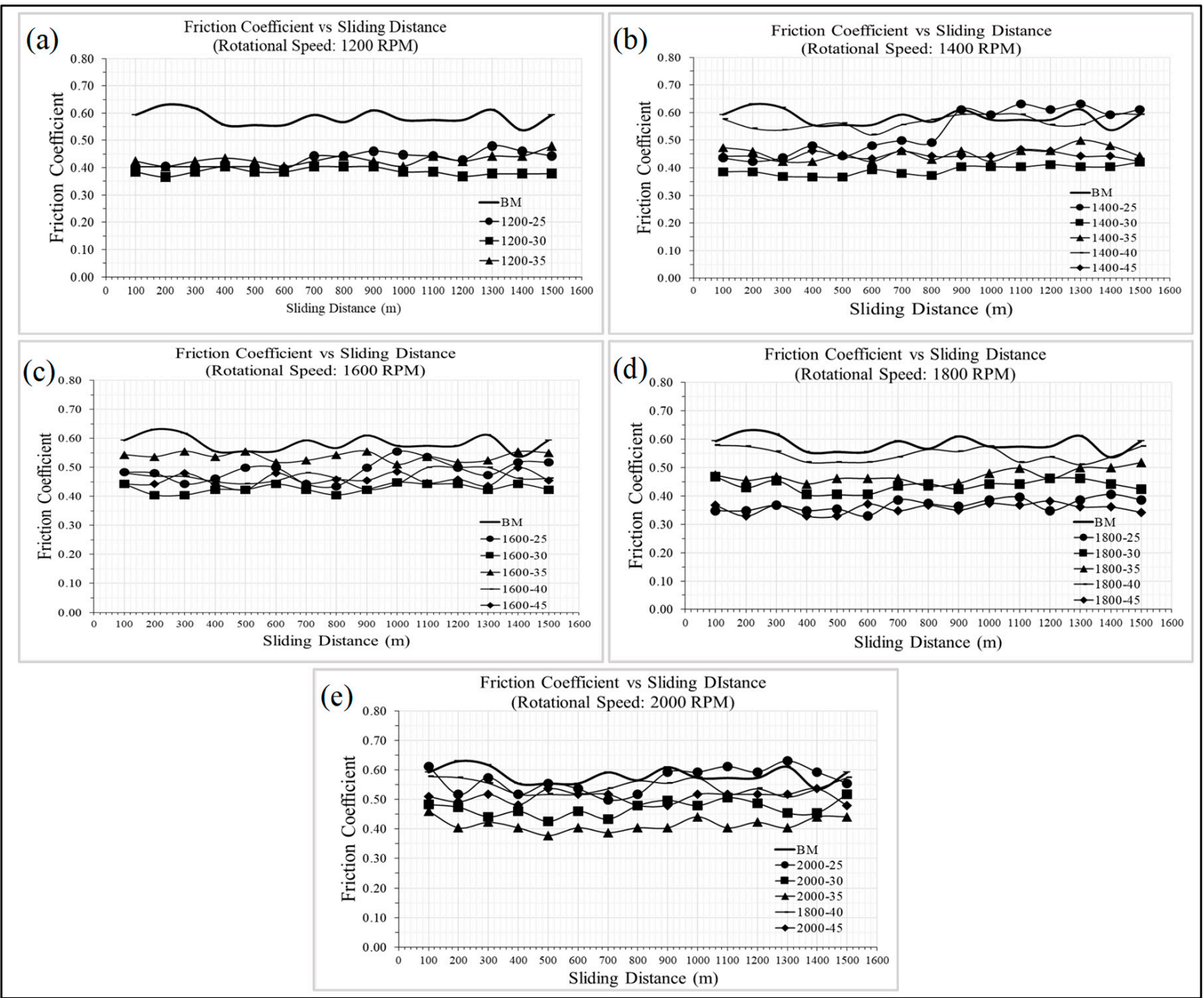

Figure 12. Sliding friction coefficient vs. sliding distance for FSPed samples produced at (a) $1200 \mathrm{rpm}$, (b) $1400 \mathrm{rpm}$, (c) $1600 \mathrm{rpm}$, (d) $1800 \mathrm{rpm}$ and (e) $2000 \mathrm{rpm}$ with different feed rate under starved lubrication conditions. (Normal contact pressure $=0.24 \mathrm{MPa}$, sliding speed $=2.88 \mathrm{~m} / \mathrm{s}$, total sliding distance $=1500 \mathrm{~m}$ ). 


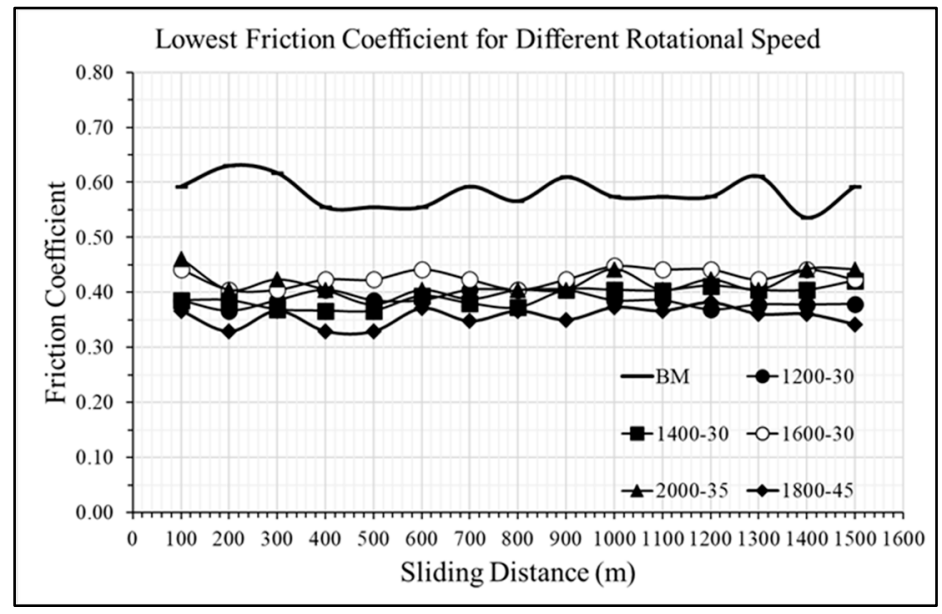

Figure 13. Sliding friction coefficient vs. sliding distance for FSPed samples with lowest friction coefficient produced by different processing parameters under starved lubrication conditions. (Normal contact pressure $=0.24 \mathrm{MPa}$, sliding speed $=2.88 \mathrm{~m} / \mathrm{s}$, total sliding distance $=1500 \mathrm{~m}$ ).

Figures 14 and 15 show the wear rate of all the FSPed samples in comparison with the wear rate of raw recycled AA 6063. Figure 14 shows that the lowest wear rate samples at each rotational speed are produced at $1200 \mathrm{rpm}$ and $30 \mathrm{~mm} / \mathrm{min}$ (Sample 2), $1400 \mathrm{rpm}$ and $30 \mathrm{~mm} / \mathrm{min}$ (Sample 5), $1600 \mathrm{rpm}$, and $40 \mathrm{~mm} / \mathrm{min}$ (Sample 12), $1800 \mathrm{rpm}$ and $35 \mathrm{~mm} / \mathrm{min}$ (Sample 16) and $2000 \mathrm{rpm}$ and $35 \mathrm{~mm} / \mathrm{min}$ (Sample 21). Among these samples, Sample 21 has the smallest wear rate of $3.15 \times 10^{-6} \mathrm{gN}^{-1} \mathrm{~m}^{-1}$, followed by Sample 2 of $3.78 \times 10^{-6} \mathrm{gN}^{-1} \mathrm{~m}^{-1}$, Sample 5 and Sample 12 of $4.24 \times 10^{-6} \mathrm{gN}^{-1} \mathrm{~m}^{-1}$, and Sample 16 of $4.42 \times 10^{-6} \mathrm{gN}^{-1} \mathrm{~m}^{-1}$. Besides, all these samples have smaller wear rates than the raw recycled AA 6063 of $6 \times 10^{-6} \mathrm{gN}^{-1} \mathrm{~m}^{-1}$. Sample 21, Sample 2, and Sample 5 have small wear rates as they also have smaller friction coefficients than many other samples. Besides, they also have high and moderately high hardness. Hence, the enhancement in wear resistance has resulted from the enhancement in microhardness and reduction in friction of the sample $[5,28]$. However, it can be observed that some FSPed samples have higher wear rates than the base metal and this may be due to the existence of third body abrasive wear during the test. Both adhesive and abrasive wear can be observed on the worn surfaces of all the FSPed samples especially those samples with higher wear rates. Figures 16 and 17 show the worn surfaces of the BM and all the FSPed samples.

Figures 16 and 17 show that the samples with the smallest wear rates mostly have adhesive wear and plastic deformation, and little material loss can be observed from the worn surface from Figure 17b,e,l,p,u. Besides, the abrasive wear coinciding with higher wear rates can be observed in the form of fractures, voids, which indicate significant material loss during the sliding test. The larger the wear rate, the more abrasive wear can be observed from Figures 16 and $17 \mathrm{a}, \mathrm{d}, \mathrm{g}, \mathrm{i}-\mathrm{k}, \mathrm{o}, \mathrm{q}, \mathrm{s}, \mathrm{t}$. Besides, both adhesive and abrasive wear can also be observed on the samples with moderate wear rates as shown in Figure $17 \mathrm{c}, \mathrm{f}, \mathrm{h}, \mathrm{m}, \mathrm{n}, \mathrm{r}, \mathrm{v}, \mathrm{w}$. 


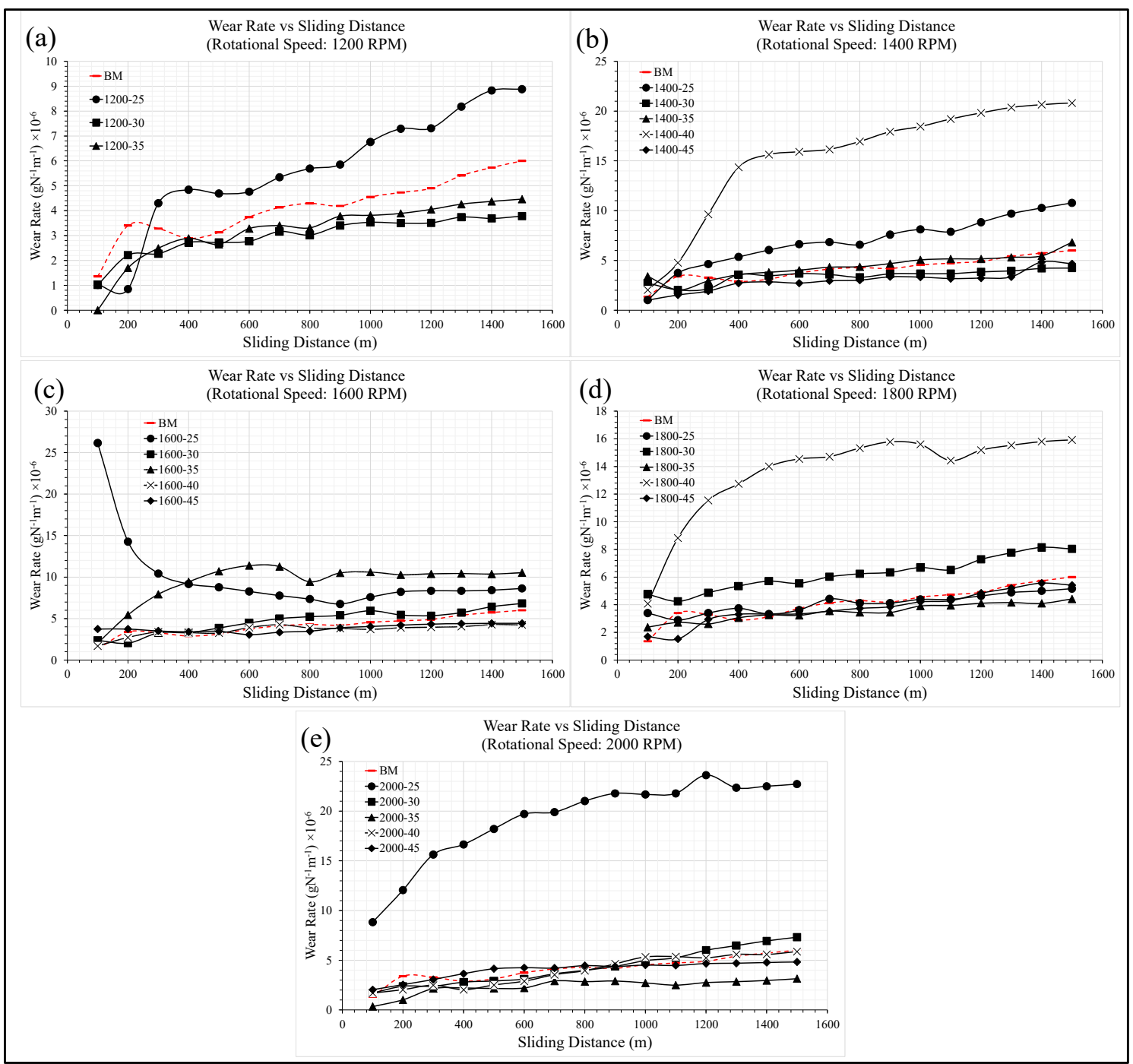

Figure 14. Wear rate vs. sliding distance for FSPed samples produced at (a) $1200 \mathrm{rpm}$, (b) $1400 \mathrm{rpm}$, (c) $1600 \mathrm{rpm}$, (d) $1800 \mathrm{rpm}$, and (e) $2000 \mathrm{rpm}$ with different feed rate under starved lubrication conditions. (Normal contact pressure $=0.24 \mathrm{MPa}$, sliding speed $=2.88 \mathrm{~m} / \mathrm{s}$, total sliding distance $=1500 \mathrm{~m}$ ).

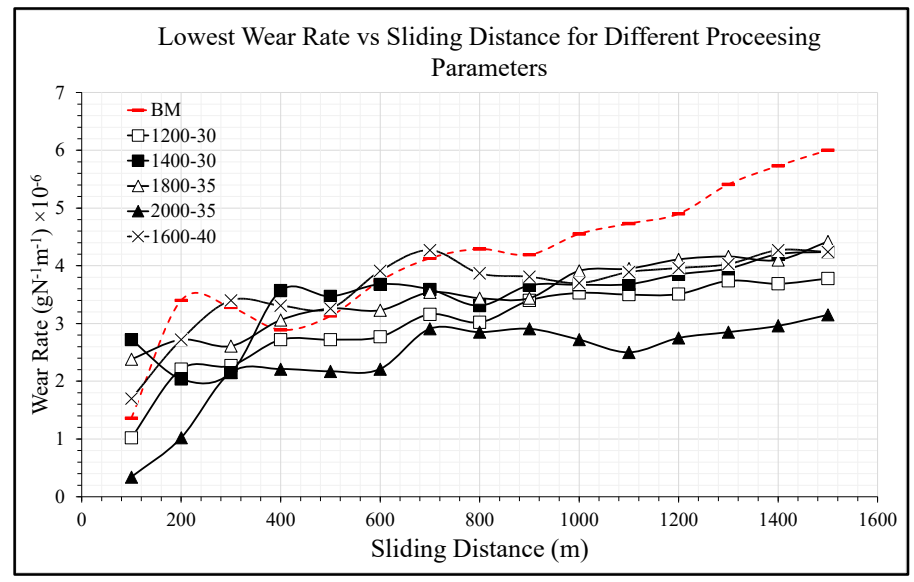

Figure 15. Wear rate vs. sliding distance for FSPed samples with the smallest wear rate produced by different processing parameters under starved lubrication conditions. (Normal contact pressure = $0.24 \mathrm{MPa}$, sliding speed $=2.88 \mathrm{~m} / \mathrm{s}$, total sliding distance $=1500 \mathrm{~m}$ ). 


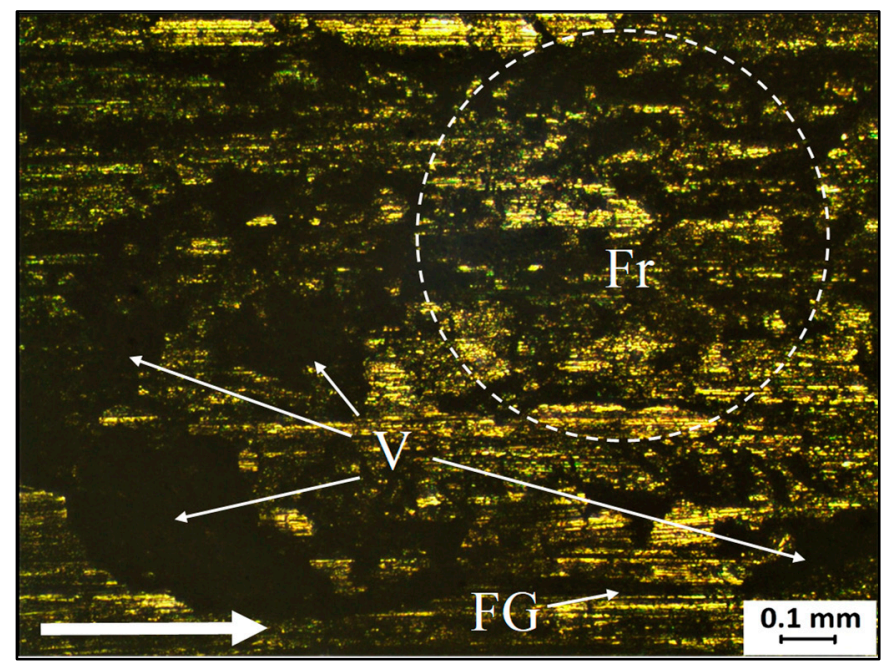

Figure 16. Wear morphology of recycled AA 6063 base metal after sliding distance test under starved lubrication conditions, normal contact pressure of $0.24 \mathrm{MPa}$, sliding speed of $2.88 \mathrm{~m} / \mathrm{s}$, and sliding distance of 1500 m. (PD: Plastic Deformation, Fr: Fracture, V: Void, and FG: Fine Groove; arrow at bottom left corner showing sliding direction).

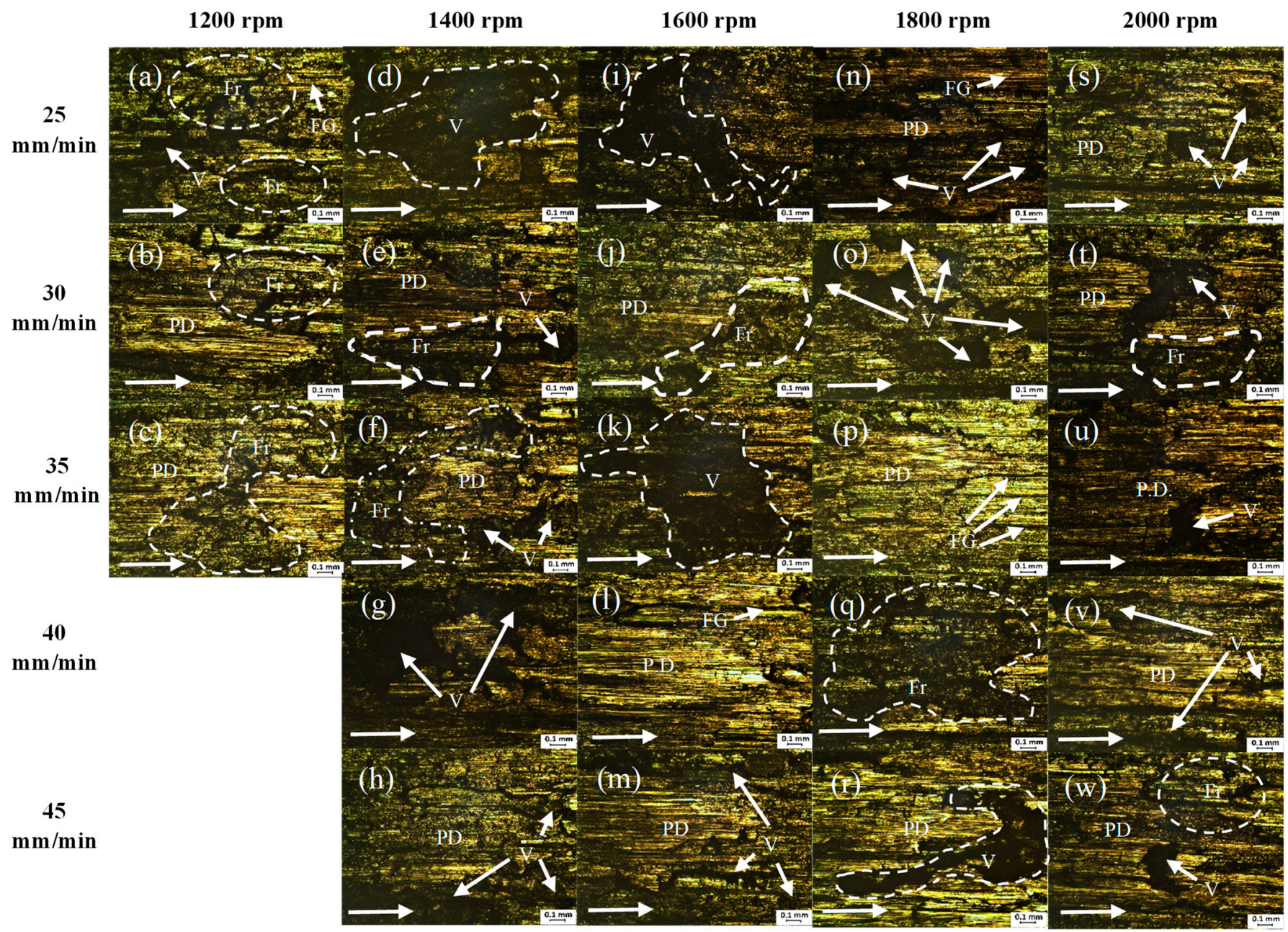

Figure 17. (a-w) Wear morphology of FSPed samples after sliding distance test under starved lubrication conditions, normal contact pressure of $0.24 \mathrm{MPa}$, sliding speed of $2.88 \mathrm{~m} / \mathrm{s}$, and sliding distance of 1500 m. (PD: Plastic Deformation, Fr: Fracture, V: Void, and FG: Fine Groove; arrows at bottom left corners showing sliding direction). 
The main purpose of this work is to optimize the FSP processing parameters of recycled AA 6063 that simultaneously maximize microhardness and minimize surface roughness for the lowest friction coefficients and wear rate. Based on the results discussed above, it is difficult to pinpoint the best processing parameters. Hence, Figure 18 was plotted to have a clearer presentation of the friction and wear performance of the FSPed samples. Figure 18 shows that the sample produced at $1800 \mathrm{rpm}$ and $25 \mathrm{~mm} / \mathrm{min}$ or $45 \mathrm{~mm} / \mathrm{min}$ has the smallest friction but they do not have the smallest wear rate. On the other hand, the sample produced at $2000 \mathrm{rpm}$ and $35 \mathrm{~mm} / \mathrm{min}$ has the smallest wear rate but it does not have the lowest friction. Besides, all these samples also do not have the highest surface microhardness. Figure 18 shows that the sample produced at $1200 \mathrm{rpm}$ and $30 \mathrm{~mm} / \mathrm{min}$ has the second-lowest friction coefficient and wear rate. Besides, this sample also produced the highest microhardness. Hence, the experimental results above show that $1200 \mathrm{rpm}$ and $30 \mathrm{~mm} / \mathrm{min}$ are the best processing parameters for the fabrication of FSPed recycled AA 6063 as they produced the highest hardness than other processing parameters and it also has a small wear rate and friction coefficient. In addition, it also has considerably low $R_{a}$ and $\mathrm{R}_{\mathrm{q}}$ values in its surface roughness.

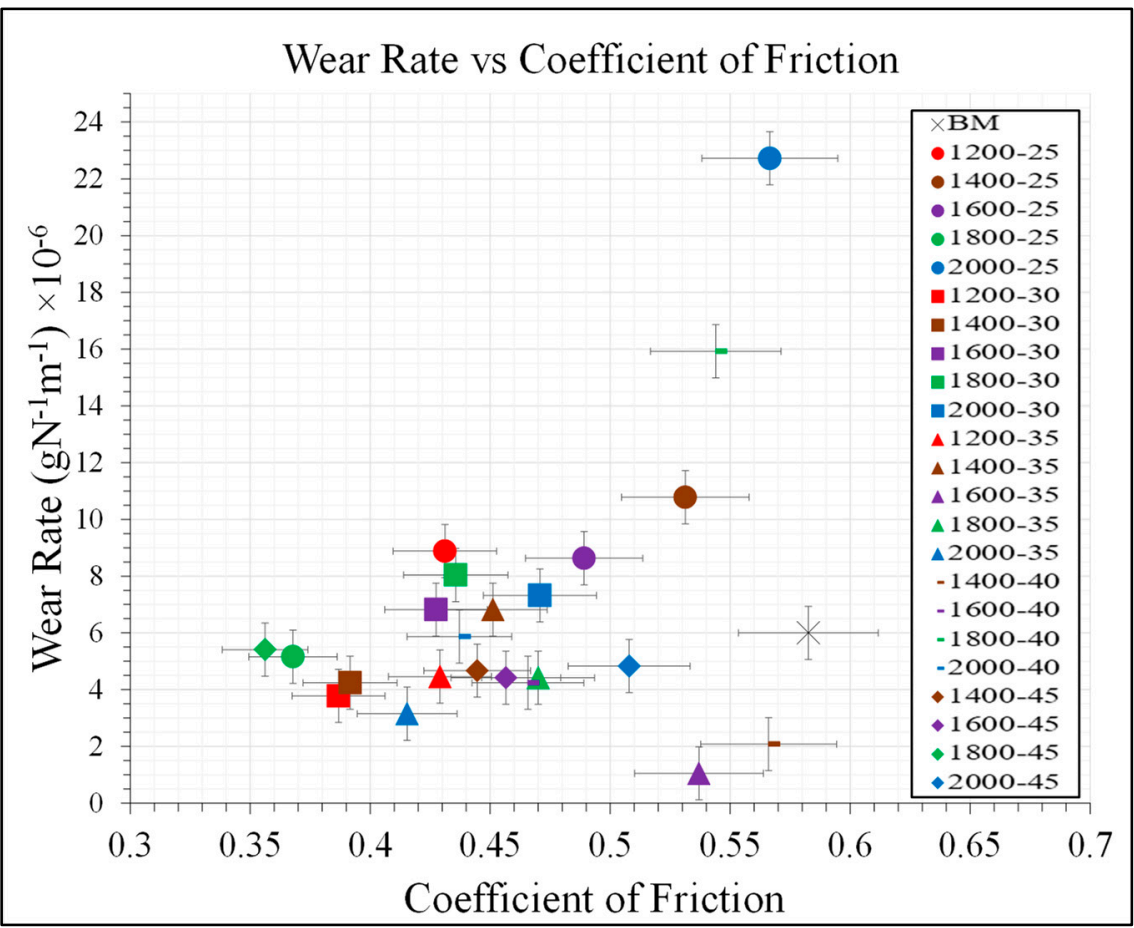

Figure 18. Friction coefficients vs. wear rates of FSPed samples after sliding tests under starved lubrication conditions, normal contact pressure of $0.24 \mathrm{MPa}$, sliding speed of $2.88 \mathrm{~m} / \mathrm{s}$, and sliding distance of $1500 \mathrm{~m}$.

\section{Conclusions}

The aim of this study was to determine the optimized processing parameters for the fabrication of FSPed recycled AA 6063 based on its surface hardness and tribological performance. The following conclusions can be drawn from this study:

- Defect-free FSPed recycled AA 6063 was successfully produced using a CNC milling machine with the groove FSP method.

- According to the surface hardness data, Sample 2 (1200 rpm and $130 \mathrm{~mm} / \mathrm{min}$ ) produced the highest average hardness value of $48 \mathrm{HV}$ which was enhanced by $25 \%$ over the base metal hardness, which is $38.5 \mathrm{HV}$.

- Microstructure inspection and the grain size measurement show that Sample 2 has a homogeneous grain structure and the smallest grain size that was refined by about $96 \%$. It also has the highest hardness among the FSPed samples. 
- The friction and wear rate of Sample 2 is also considerably lower than other FSPed samples. Its wear resistance was enhanced by about $37 \%$ and its friction was reduced by $33 \%$. Wear morphology shows that Sample 2 has mostly adhesive wear and only slight fractures

- In all other samples, more fractures can be observed as the wear rate increases. Both adhesive wear and abrasive wear can be observed from the FSPed samples.

- In a nutshell, the optimized processing parameters for FSPed recycled AA 6063 are a rotational speed of $1200 \mathrm{rpm}$ and a feed rate of $30 \mathrm{~mm} / \mathrm{min}$.

Author Contributions: Conceptualization, K.W.L. and G.S.T.; Methodology, K.W.L. and G.S.T.; Formal analysis, K.W.L. and G.S.T.; Investigation, K.W.L., G.S.T. and C.K.K.; Resources, K.W.L.; Data curation, G.S.T.; Writing—original draft preparation, K.W.L. and G.S.T.; Writing—review and editing, K.W.L., C.K.K. and G.S.T.; Supervision, K.W.L.; Project administration, K.W.L.; Funding acquisition, K.W.L. and C.K.K. All authors have read and agreed to the published version of the manuscript.

Funding: This research was funded by Fundamental Research Grant Scheme, [FRGS/1/2019/TK03/ MMU/02/6].

Institutional Review Board Statement: Not applicable.

Informed Consent Statement: Not applicable.

Data Availability Statement: Data available on request.

Acknowledgments: This work was supported by the Fundamental Research Grant Scheme (FRGS), Ministry of Higher Education, Malaysia. The authors gratefully acknowledge EL Aluminium Billet Sdn. Bhd. and Impressive Edge Sdn. Bhd. for the technical and partial financial support rendered. Special thanks to the Faculty of Engineering and Technology of Multimedia University for their support in allowing this research to be carried out.

Conflicts of Interest: The authors declare no conflict of interest.

\section{References}

1. Ozer, G.; Burgucu, S.; Marsoglu, M. A Study on the Recycling of Aluminum Alloy 7075 Scrap. Mater. Test. 2012, 54, 175-178. [CrossRef]

2. Wallace, G. Production of secondary auminium. In Fundamentals of Aluminium Metallurgy: Production, Processing and Applications, 1st ed.; Roger, L., Ed.; Woodhead Publishing Limited: Sawston, UK, 2010; pp. 70-82.

3. Gholami, S.; Emadoddin, E.; Tajally, M.; Borhani, E. Friction stir processing of $7075 \mathrm{Al}$ alloy and subsequent aging treatment. Trans. Nonferrous Met. Soc. China 2015, 25, 2847-2855. [CrossRef]

4. Wessel, J.K. The Handbook of Advanced Materials: Enabling New Design; John Wiley \& Sons, Inc.: Toronto, ON, Canada, 2004.

5. Amirafshar, A.; Pouraliakbar, H. Effect of Tool Pin Design on the Microstructural Evolutions and Tribological Characteristics of Friction Stir Processed Structural Steel. Meas. J. Int. Meas. Confed. 2015, 68, 111-116. [CrossRef]

6. Karthikeyan, L.; Senthil Kumar, V.S. Relationship between Process Parameters and Mechanical Properties of Friction Stir Processed AA6063-T6 Aluminum Alloy. Mater. Des. 2011, 32, 3085-3091. [CrossRef]

7. Al-Fadhalah, K.J.; Almazrouee, A.I.; Aloraier, A.S. Microstructure and Mechanical Properties of Multi-Pass Friction Stir Processed Aluminum Alloy 6063. Mater. Des. 2014, 53, 550-560. [CrossRef]

8. Wȩglowski, M.S.; Hamilton, C.B. An Experimental Investigation and Modelling of Friction Stir Processing. Eng. Trans. 2013, 61, 65-80.

9. Smith, C.B.; Harington, J.; Kouch, T. Friction Stir Processing for Efficient Manufacturing; Friction Stir LInk, Inc.: Milwaukee, WI, USA, 2012; pp. 1-35.

10. Lorenzo-Martin, C.; Ajayi, O.; Smith, C.; Krol, S. Energy Efficient Surface Hardening of 4140 Steel by Friction Stir Processing for Tribological Applications. In Proceedings of the ASME/STLE 2011 International Joint Tribology Conference. ASME/STLE 2011 Joint Tribology Conference, Los Angeles, CA, USA, 24-26 October 2011; pp. 63-65.

11. Sharma, V.; Prakash, U.; Kumar, B.V. Surface Composites by Friction Stir Processing: A Review. J. Mater. Process. Technol. 2015, 224, 117-134. [CrossRef]

12. Gibson, B.T.; Lammlein, D.H.; Prater, T.J.; Longhurst, W.R.; Allun, M.C.; Dharmaraj, K.J.; Cook, G.E.; Strauss, A.M. Friction Stir Welding: Process, Automation, and Control. J. Manuf. Process. 2014, 16, 56-73. [CrossRef]

13. Teo, G.S.; Liew, K.W.; Kok, C.K. Enhancement of Microhardness and Tribological Properties of Recycled AA 6063 Using Energy-Efficient and Environment-Friendly Friction Stir Processing. In Proceedings of the IOP Conference Series: Earth and Environmental Science, Sapporo, Japan, 26-28 August 2021; IOP Publishing: Bristol, UK, 1874.

14. Węglowski, M.S. Friction Stir Processing—State of the Art. Arch. Civ. Mech. Eng. 2018, 18, 114-129. [CrossRef] 
15. Kumar, S. Ultrasonic Assisted Friction Stir Processing of 6063 Aluminum Alloy. Arch. Civ. Mech. 2016, 16, 473-484. [CrossRef]

16. Kumar, S.; Santhanam, V. Single Point Incremental Forming of Friction Stir Processed Al 6063-O Alloy. In Proceedings of the ASME 2015 International Mechanical Engineering Congress and Exposition. Volume 2A: Advanced Manufacturing, Houston, TX, USA, 13-19 November 2015; pp. 2-7.

17. Zhao, H.; Pan, Q.; Qin, Q.; Wu, Y.; Su, X. Effect of the Processing Parameters of Friction Stir Processing on the Microstructure and Mechanical Properties of 6063 Aluminum Alloy. Mater. Sci. Eng. A 2019, 751, 70-79. [CrossRef]

18. Mahmoud, T.S. Effect of Friction Stir Processing on Electrical Conductivity and Corrosion Resistance of AA6063-T6 Al Alloy. J Mech. Eng. Sci. 2008, 222, 1117-1123. [CrossRef]

19. Babu, J.; Anjaiah, M.; Mathew, A. Experimental Studies on Friction Stir Processing of AZ31 Magnesium Alloy. Mater. Todays 2018, 5, 4515-4522. [CrossRef]

20. Surekha, K.; Murty, B.S.; Prasad Rao, K. Comparison of Corrosion Behaviour of Friction Stir Processed and Laser Melted AA 2219 Aluminium Alloy. Mater. Des. 2011, 32, 4502-4508. [CrossRef]

21. Surekha, K.; Murty, B.S.; Prasad Rao, K. Effect of Processing Parameters on the Corrosion Behaviour of Friction Stir Processed AA 2219 Aluminum Alloy. Solid State Sci. 2009, 11, 907-917. [CrossRef]

22. Shanmugasundaram, A.; Arul, S.; Sellamuthu, R. Investigating the Effect of WC on the Hardness and Wear Behavior of Surface Modified AA 6063. Mater. Todays 2018, 5, 6579-6587. [CrossRef]

23. Rathee, S.; Maheshwari, S.; Siddiquee, A.N.; Srivastava, M. Analysis of Microstructural Changes in Enhancement of Surface Properties in Sheet Forming of Al alloys via Friction Stir Processing. Mater. Today Proc. 2017, 4, 452-458. [CrossRef]

24. Srivastava, M.; Rathee, S.; Maheshwari, S.; Siddiquee, A.N. Optimization of Friction Stir Processing Parameters to Fabricate AA6063/SiC Surface Composites Using Taguchi Technique. Int. J. Mater. Prod. Technol. 2019, 58, 16-31. [CrossRef]

25. Murali, S.; Chockalingam, A.; Suresh Kumar, S.; Remanan, M. Production, Characterization and Friction Stir Processing of AA6063-T6 / Al3Tip in-situ Composites. Int. J. Mech. Prod. 2018, 2018, 399-406.

26. Liew, K.W.; Chung, Y.Z.; Teo, G.S.; Kok, C.K. Effect of Tool Pin Geometry on the Microhardness and Surface Roughness of Friction Stir Processed Recycled AA 6063. Metals 2021, 11, 1695. [CrossRef]

27. Cavaliere, P.; Squillace, A. High Temperature Deformation of Friction Stir Processed 7075 Aluminium Alloy. Mater. Charact. 2005, 66, 136-142. [CrossRef]

28. Yasavol, N.; Ramalho, A. Wear Properties of Friction Stir Processed AISI D2 Tool Steel. Tribol. Int. 2015, 97, 177-183. [CrossRef]

29. Mishra, M.K.; Rao, A.G.; Balasundar, I.B.; Kashyap, P.; Prabhu, N. On the Microstructure Evolution in Friction Stir Processed 2507 Super Duplex Stainless Steel and Its Effect on Tensile Behaviour at Ambient and Elevated Temperatures. Mater. Sci. Eng. A 2018, 719, 82-92. [CrossRef]

30. Chainarong, S.; Muangjunburee, P.; Suthummanon, S. Friction Stir Processing of SSM356 Aluminium Alloy. Procedia Eng. 2014, 97, 732-740. [CrossRef]

31. Behnagh, R.A.; Shen, N.; Abdollahi, M.; Ding, H. Ultrafine-Grained Surface Layer Formation of Aluminum Alloy 5083 by Friction Stir Processing. Procedia CIRP 2016, 45, 243-246. [CrossRef]

32. Zhou, Y.; Zhu, H.; Zhang, W.; Zuo, X.; Li, Y. Influence of Surface Roughness on the Friction Property of Textured Surface. Adv. Mech. Eng. 2015, 7, 1687814014568500. [CrossRef]

33. Ivkovic, B.; Djukdjanovi, M.; Stamenkovic, D. The Influence of the Contact Surface Roughness on the Static Frictio Coefficient. Tribol. Ind. 2000, 22, 41-44.

34. Stamenkovic, D.; Sundaresan, R. Effect of Hardness and Surface Roughness on Slip Resistance of Rubber Effect of Hardness and Surface Roughness on Slip Resistance of Rubber. J. Test. Eval. 2015, 43, 1574-1586. 